\title{
VII Excursus: Paradigm Change within Historical Caribbean Research and Its Narrative Representation
}

In this chapter, I would like to jump from the nineteenth century to the present, using two Caribbean writers as contemporary reference points, namely Raphaël Confiant and Maryse Condé. While my aim with Confiant is to look at a narrative representation of the nineteenth century and to show how theory production in the contemporary Caribbean cannot manage without reference to the nineteenth century, a parallel reading of Condé and of Gómez de Avellaneda shows the extent to which looking backwards from contemporary literary texts can enrich the reading of a nineteenth-century literary text in key ways. With his theory of coolitude, Khal Torabully, a cultural theoretician, film director, and writer from Mauritius, brings the Indian dimension into play, a dimension that goes beyond essentialism and broadens the formation of the Caribbean paradigm and that also refers back to the nineteenth century and the experience of the ship crossing. And finally, by bringing in the contemporary writers J.-M.G. Le Clézio, Édouard Glissant, and Epeli Hau'Ofa, I open up a transoceanic perspective among the Indian, Atlantic, and Pacific Oceans and bring up the question of an archipelagic or transoceanic avant-garde.

\section{VII.1 Reading Gómez de Avellaneda with Maryse Condé}

I want to look here at two novels by Caribbean women writers: $\mathrm{Sab}$, by Gertrudis Gómez de Avellaneda (1841), and Traversée de la Mangrove (Crossing the Mangrove), by Maryse Condé (1989) (see also Müller, “Transkoloniale Dimensionen”; Müller, "Variantes de miradas"). What can this juxtaposition tell us? What, besides geographical space and the gender of the writers, connects these two novels, which are separated in time by almost a hundred and fifty years?

In both of these novels the authors are dealing with their islands of origin, which are isolated enclaves with the status, then as now, of colonies or overseas departments, surrounded by other islands that are already politically independent; in addition, the writers are also trying to connect their islands of origin more firmly (again) into their regional contexts, given the loosening of cultural ties to the center. Both of these writers dramatically embody the problematics of the inbetween: after leaving their countries of origin at a very early age (Avellaneda around 1837 and Condé around 1953), they devote their literary labors (or at 
least a part of them) to their homeland, or rather what they call their homeland, not least because of a latent experience of foreignness in their host and mother countries of Spain and France.

Both of them argue, in the context of writing from the outside-that is to say, from the distance of a so-called center-for a stronger emphasis on what is specifically Cuban or, respectively, Guadeloupean; both of them experience a sense of alienation ${ }^{1}$ on their return to their island of origin, among other things because they are perceived as strangers. This experience, which is symptomatic and traumatizing for many intellectuals from colonies or former colonies, reflects an issue that lies even deeper and that both of these writers anticipate and reflect on, in similar ways: as we have already seen for Gómez de Avellaneda, the attempt to make the metropolis's categories of identity serviceable for the description of what is proper to the non-European leads to an in-between, in other words to a tension that can usually not be resolved through a dialectial synthesis. Both of these writers show themselves to be extraordinarily sensitive to this tension in their writing about the in-between. In both of them, this sensitivity is expressed in a similarly ambivalent way of dealing with the question of their own authorship, a theme that then becomes a nodal point for a whole series of subtle crossings of borders that call existing gender and ethnic hierarchies into question; in both cases of literary representation, issues around the construction of personal and collective identity are presented as tightly interconnected with each other.

To be more concrete, both Gómez de Avellaneda and Condé take back their authorship, in a certain way, when they integrate their writing process itself into the novel and attribute it to their protagonist-in both cases a man. In Avellaneda's novel, the entire story turns out at the end to have been a farewell letter from the slave and title character, Sab; in Condé, the dead main character, Francis, around whose nighttime funeral the many stories wind, turns out to be a novelist who had been working on a novel entitled "Crossing the Mangrove."2

\section{VII.1.1 Mangroves and the Staging of a Relational Identity}

While all of the plotlines in Avellaneda's novel lead to Sab, who then finally, as the narrator as well as the main character, moves into the indispensable integra-

1 On the description of Condé's feeling of foreignness and alienation, see Ette, Literature on the Move $274 \mathrm{f}$.

2 On Crossing the Mangrove, see Ette's essential interpretation in "Crossing the Mangrove." On strategies of authorship in Condé, see Gewecke, "Der Titel als Chiffre einer Subversion” 171. 
tive center of the construction of identity there, in Maryse Condé's Crossing the Mangrove, the conceptions of identity are more fragmented and decentralized, even though many of the basic formal and substantive constellations are totally comparable to those in Sab. Like Avellaneda, Maryse Condé relinquishes her authorship, at least in part, to her protagonist, Francis Sancher alias Francisco Alvarez Sanchez. Thus, for example, his former lover Vilma tells of their first meeting in his house, where she saw him working on a manuscript. When she asked what he was writing, he answered:

\footnotetext{
“You see, I'm writing. Don't ask me what's the point of it. Besides, I'll never finish this book because before I've even written the first line and known what I'm going to put in the way of blood, laughter, tears, fears, and hope, well, everything that makes a book a book, ... I've already found the title: "Crossing the Mangrove."”

I shrugged my shoulders.

"You don't cross a mangrove. You'd spike yourself on the roots of the mangrove trees. You'd be sucked down and suffocated by the brackish mud."

"Yes, that's it, that's precisely it." (Condé, Crossing the Mangrove 158) ${ }^{3}$
}

Thus, the project of identity is doomed to failure from the beginning. We can read the doubled authorial structure as an indication that it took the female writer Condé to complete the project of a "rhizomatic" identity (as defined by Deleuze and Guattari; cf. Ette, Literature on the Move $284 \mathrm{ff}$.) and to make it possible to navigate the mangrove roots-roots that are not primarily anchored in the depths of the earth (read history), as with Western trees, but that find their rootedness on the surface instead, horizontally, intertwined with each other like branches and so that the individual plants support each other. This is an argument for a relational identity, as opposed to a root-identity (to use Édouard Glissant's terms; cf. Ette, Literature on the Move 274). And yet it nevertheless becomes clear that the question of the representation of authorship is not insignificant here, because the structure of the novel actually answers this question quite

3 -Tu vois, j'écris. Ne me demande pas à quoi ça sert. D'ailleurs, je ne finirai jamais ce livre puisque, avant d'en avoir tracé la première ligne et de savoir ce que je vais y mettre de sang, de rires, de larmes, de peur, d'espoir, enfin de tout ce qui fait qu'un livre est un livre et non pas une dissertation de raseur, la tête à demi fêlée, j'en ai déjà trouvé le titre: “Traversée de la Mangrove".

J'ai haussé les épaules.

-On ne traverse pas la mangrove. On s'empale sur les racines des palétuviers. On s'enterre et on étouffe dans la boue saumâtre.

-C'est ça, c'est justement ça (Traversée de la Mangrove 202-203). Cf. Ette, Literature on the Move 264). 
clearly. The novel has twenty chapters, and every chapter is a story told by a different narrator. The narrators are the participants in a wake for Francis.

Much like in García Márquez's Hundred Years of Solitude, the plot of Crossing the Mangrove takes place in the closed microcosm of a village, in this case the godforsaken Guadeloupean village of Rivière au Sel, where so far the inhabitants have apparently lived alongside each other in a very isolated and uncommunicative way. But what creates a feeling of belonging among them is not the eternal succession of generations within a shared mythical, magical world of imagination but rather the numerous interwoven connections among the individual villagers. Where in García Márquez's origin story we find the circular and almost metabolic diachronicity of never-changing sameness, the narrated time presented in Condé is extraordinarily compact and concise, which reinforces the impression of the synchronicity of the varied interpersonal connections. Thus, it takes Sancher's (mysterious) death to not only bring the villagers together at his burial but also to make them aware of the dynamic of their network of relationships, a dynamic that is only created in the first place through the verbal interaction of the villagers telling each other their stories. As an attempt at constructing identity, therefore, Sancher's novel must fail, because relational identity can no longer even be described by one single author (Malena 69); it requires, instead, the dissolution of authorial control in favor of a multiplicity of narrators, who only even constitute identity in the first place-which in this case means dynamic connection-through the overlapping and interweaving of their stories. The juxtaposition of their stories without the benefit of any single stage direction, autonomously fitting together into the mosaic of a microcosm, shows that their cohesion and their equality are based not on any overarching general principle-for instance, something symbolized in an overlaid narrative-but instead only on the shared, interactive initiative that they themselves take in speaking up.

While in $S a b$, an oppressed subject takes authorial initiative and finds his way to his own literary voice, which then becomes the mouthpiece and the center for colonial subjects trapped and entangled in a great variety of relationships of dependence and power, in Condé in many ways the protagonist-as the center around which the various polyphonic voices circle, as though in a centrifugeconstitutes a void or is, in a peculiar way, set aside.

On the one hand, no one really knows anything concrete about Sancher's past: at some point, he came to the village from somewhere else, and he has two names, the French name Francis Sancher and a Spanish equivalent, Francisco Alvarez Sanchez, which does not resolve the question of whether he is now Guadeloupean, or maybe Colombian-but all conjectures remain within the Caribbean region. When he moved into an old, abandoned house, the locals looked at him suspiciously for a long time and always considered him a stranger, until 
the stories they tell at the wake reveal that each of them has a particular relationship to him. On the other hand, Sancher-who worked on the manuscript of "Crossing the Mangrove" and came to the realization that in so doing he had devoted himself to a hopeless undertaking-is the only one who does not have a chance to tell any stories. His death, and with it the renunciation of any initiative, is in this case the prerequisite for initiative on the part of the many. Barthes's saying about the death of the author plays out very literally here, except that the author's authority does not give way to some self-referentiality, in whatever form, of an anonymous, subject-less text, but rather to multiple voices and to an interactive referentiality.

The openness of the text is key for this interactivity and intersubjectivity, and the fact that these narratives are oral narratives is crucial for the text (see Ette, Literature on the Move 265). Their juxtaposition in the context of oral communication puts them at the intersection of, on the one hand, an unchangeable past, and, on the other, a dynamic present that points the way towards an open future and that is under the control of the actors themselves. In diachronic perspective, as a completed narrative, each story points backwards into a past that also reveals the Guadeloupe of that time to be full of stereotypes and essentialist attributions of identity. As in Avellaneda's novel, skin color and gender are still the most important factors here, even though several of the speakers indicate that education had recently become an important factor in social identity, only to then be pushed aside by what is then, most recently of all, the only valid social measure: the bank balance-a criterion that in Sab only means something to the illegitimate Otways. From this perspective, Guadeloupe is finally still a heterogeneous patchwork, a society without cohesion, divided and seamed in many ways.

From a synchronic perspective, however, as open communication, the stories within these narratives become the basis of encounter and a pluralist exchange. It is the individual background of each person and the story told by that person-not the sameness of them all-that allows each of them to have their own perspective on what they do all share: in this story, concretely, their memory of the dead man and through that of their shared village, which stands as a microcosm for the entire island. It is these different standpoints that make communication meaningful in the first place, and it is only in their communicative exchange, in the dynamic of narrating, listening, and answering, that the villagers can recognize themselves and each other as equal, in the sense of having equal rights, on the basis of their very difference. Through their shared center, the "dead author," they speak not against each other, but with each other.

Both of these novels portray the Caribbean as an extraordinarily productive and, above all, self-sufficient cultural and literary space that produces an un- 
heard-of conceptual depth out of the very dilemma of identity posed by its heterogeneity. To put it another way, it is precisely the gap between Europe and their island of origin-even though, because of their divided biographies, their intellectual sense of belonging does not accord with their emotional one-that challenges these writers to their productive engagement with contemporary European discourses, discourses that both of these writers, in different ways (and of course in the context of their respective times), definitely understand in the dialectical tension between liberation and dominance, even though the recognition of this ambivalence does not therefore protect them from the doubled experience of alienation.

In the attempt to overcome the essentialist model of identity-an attempt that is, in my opinion, constitutive of both novels, each in its own way-Condés novel, unsurprisingly, offers a more convincing alternative than Avellaneda's Sab was able to do in the first half of the nineteenth century. Although it is oriented towards the relational identity of the poststructuralists, this model is marked by its own very particular nuance. The perspective it provides based on multiple voices and an interactive dynamic is certainly more consistent than that of Sab, who is a figure of integration, consisting precisely of the utopia (which has a Christian character) of his own self-sacrifice. Nevertheless, it may still be that, even given all of the mangrove's conceptual persuasiveness, Sab, with his emotional appeal and the shock that his self-sacrifice produces in the reader, makes a greater historical impact. It is the very interplay between these two ways of reading that reveals the universal dimension of Caribbean literatures.

\section{VII.2 Raphaël Confiant}

The contemporary literary production of the French-speaking Caribbean finds itself in an exceedingly complicated cultural and political situation. Its orientation towards both the Parisian literary industry and the mainland French academic world, on the one hand, and its Caribbean and Latin American neighbors, on the other, only intensifies the question of where, exactly, the literary field of today's French Antilles is located. In France, the literary industry and the academy are closely connected, and so it is no coincidence that most of the well-known writers of the French Antilles are also professors of literary studies. This intersection of literary production and cultural-theoretical reflection is particularly salient in the case of Raphaël Confiant (see also Müller, "Raphaël Confiant”; Müller, "Modelos caribeños").

Raphaël Confiant was born in 1951 and has taught English language and literature at the University of the French West Indies and Guiana, in Martinique, 
since 1979. He first wrote in Creole; in 1988 he wrote his first novel in French, Le Nègre et l'Amiral (The Negro and the admiral). In 1993, he received the Casa de las Américas prize and the Jet Tours prize for his novel Ravines du devantjour (Ravines of early morning). He and Patrick Chamoiseau were the co-creators of Créolité, which builds on earlier movements such as négritude and Antillanité and strives to develop a new, multi-voiced concept of identity which, unlike the ideas of their peer, Édouard Glissant, exhibits a concrete connection to Antillean societies and is thus exposed to the critique that it has developed a new essentialism.

The following discussion is intended to serve as an examination of the relevance of research on the nineteenth-century Caribbean to present-day narrative representations of the Caribbean. In looking at contemporary literature, given that literary scholarship very often considers Latin America and the Caribbean together, the question arises of the degree to which the writing in France's overseas departments can be differentiated from current Latin American productions. This question consciously goes against the grain of the tendency to do away with regional categorizations altogether (as in the Crack Manifesto ${ }^{4}$ ). On the other hand, the connection between Caribbean theoretical productionwhich has made a name for itself in literature and philosophy, especially in the canonized texts of Derek Walcott, Édouard Glissant, and Benítez Rojoand literary forms of expression is of particular interest. I focus on how the paradigm of identity is dealt with, although among all of the variation in how the most recent Latin American and Caribbean literatures express themselves, one thing they share is surely their general renunciation of this paradigm. It is no surprise, given his commitment to Créolité, that Raphaël Confiant is one of the main actors here. His 2005 novel Adèle et la pacotilleuse is set in the second half of the nineteenth century in the Caribbean, its diaspora (with a center in Halifax, Canada), and in France. The most immediate question that arises here is whether that novel is a new historical novel, along the lines of García Márquez's Bolivar novel, El general en su laberinto (The General in His Labyrinth) or Carlos Fuentes's La campaña (The Campaign).

4 Crack is the name of a group of Mexican writers, all born around 1968, whose 1998 Crack Manifesto (Manifiesto Crack) calls for a conscious departure from magical realism, which was all too dominant in Latin America. Its most important representatives are Jorge Volpi and Ignacio Oadilla. See Müller, Die Boom-Autoren heute 280-281. 


\section{VII.2.1 Adèle et la pacotilleuse (Adèle and the Tinkerwoman)}

Driven by her unhappy love affair with Albert Pinson, a British officer, Adèle Hugo (the daughter of the great French poet) goes to North America in search of him. After several years in Canada, during which Pinson apparently fails to reciprocate her love, she follows him to Barbados, where she learns that he is actually in Burma. A tinkerwoman named Céline Alvarez Bàà-a pacotilleuse, peddling small goods among the Caribbean islands-finds her in this situation, deeply unhappy, in mental distress, caught between two black men who are fighting over her. Céline, of African, Andalusian, and Caribbean descent, develops a maternal relationship towards the white Frenchwoman, taking care of Adèle from that point on with selfless solicitude and doing everything in her power to help the disturbed young woman reach her father. She takes the young lady to St. Pierre, in Martinique, where through great difficulties, and with the help of Verdet, a wealthy admirer of Hugo's, she succeeds in making contact with the poet in France. In the meantime, Adèle is put into a sanitarium, but Céline is able to get her out again and, with Verdet's help, to make the trip to Paris in April of 1872.

After a short-term recovery, however, it becomes clear that Adèle's mental disorder cannot be reversed. Céline, who has become Hugo's mistress, returns to the Caribbean and asks Hugo to let Adèle go with her because she does better in the Antilles, but he refuses. When Céline is back in the Caribbean, however, she receives a letter from Hugo asking her to return to Paris, since he has noticed that Céline is the only person who can calm his daughter. She makes a second trip in the fall of 1872, and for the first time Hugo treats Céline as an adult. He asks her to stay with his daughter, because he is about to die, but she refuses and returns to the Caribbean for good. Although Céline asks Hugo not to put Adèle into an institution, he does it anyway for fear that his heirs might otherwise put his daughter out onto the street after his death.

Confiant divides his novel into seven chapters, using a polyphonic narrative style in which a narrator and the protagonists take turns speaking. This allows for a variety of perspectives and also involves the frequent use of fragments of several Caribbean languages. Because Confiant does without any linear description of time or place, the whole picture of an event sometimes does not become clear until it has been mentioned the second or third time. This leads to an unusual reading experience. Although the novel is written in French, we learn that this is nothing more than an official language for many. When Céline arrives in Bordeaux, her linguistic world is described as existing somewhere between French and Spanish, and it turns out that her French is actually not very strong, because everywhere where French had been spoken, Creole was spoken as well. 
Céline also prays only in Spanish or English, but not in French. In terms of the variety of languages, the key scene is the moment when Céline learns that her mother is on her deathbed in Haiti. She visits Chrisopompe to have him write a farewell letter for her, and she cannot decide on a language. She finally chooses Creole, and Chrisopompe turns out to be a true master in writing this language, which does not actually have a written form. He is inspired by François Marbot, who had written "Fables de la Fontaine travesties en créole par un vieux commandeur” (La Fontaine's fables distorted into Creole by an old commander) in around 1850. Another fascinating and very inventive passage describes a seance held by Céline, Adele, and Victor Hugo to summon spirits on the evening of April 22, 1872, at ten thirty in the evening. The first question that they ask the spirit is what language they should speak.

\section{VII.2.2 From Insularity to an Archipelagic Model}

The two women, Adèle and Céline, could not be more different from each other. One of them embodies Europe and the other the Caribbean, in its entire diversity, a diversity that is seen more as a treasure than as a handicap. This diversity can be divided up in many ways but also unified in one place or person, as with the character of Céline and the other tinkerwomen. They are the ones who speak the languages of this world, they connect the islands, and they are also the ones who, with their wares, allow their buyers to experience other worlds. The Caribbean functions as a mirror and a miniature model of the entire world, with influences from Europe, the Levant, and the Orient, through India, and all the way to China (Confiant, Adèle 69-72). As Confiant puts it: "Each island, mysteriously, has its own favorite product, a commodity, a plant, a tool, special potions and ointments, fabrics that are scorned elsewhere. But much of this does not even come from the archipelago. The entire planet seems to be pouring out its dreams there" (69). Every island on which the tinkerwomen buy their wares has its own specialty. In Cuba it is mirrors and combs made of Chinese tortoiseshell; in Trinidad, where the indigenous population is still relatively large, there are spices from India. In St. Pierre, in Martinique, there is silk from Syria, Palestine, and Lebanon-it is the Little Paris of the Antilles. Céline buys her wares from Abdelwahab El Fandour and sells her silk in St. Vincent and Granada. The imports

5 "Chaque île, mystérieusement affectionne un produit, une marchandise, une plante, un outil, des philtres et des onguents particuliers, des tissus dédaignés ailleurs. Pourtant, beaucoup de tout cela ne provient pas de l'Archipel. Toute la planète semble y déverser ses rêves.” 
from industrialized Europe include encyclopedias, pocket watches, binoculars, pens and inkwells, saws and hammers, compasses and rulers. Sometimes the tinkerwoman comes upon a one-of-a-kind piece, like the old Chinese merchant's crystal hourglass that Céline has been dreaming of and that he has promised her after his death. Every time that she leaves Jamaica, she is afraid that she will never see the piece again, fearing that his hut will be plundered before she returns. Five years later he dies of the flu, cared for by Céline, who receives the hourglass, filled with sand from the Gobi Desert. She keeps it for two years, but then she sells it to a plantation owner for a couple of pieces of gold, which she will regret for the rest of her life. Granada has the best nutmeg and the rum from Martinique is the "emperor of rums" (l'empereur des rhums). And the coffee from Guadeloupe and the tobacco from Cuba are preferred to all others $(78-82)$.

When Adèle meets Céline, the older woman is 42 years old. Born on the sea, she is the "daughter of no land, of none of those islands that the Spaniards, English, French, Dutch, Danish, Swedish, and Americans have been fighting over for centuries" $(61-62){ }^{6}$ She talks about the tinkerwomen, the vagabonds of the Caribbean Sea who have no homeland and who make the sea their home, as:

we, the tinkerwomen, women of ocean wanderings, more so, anyway, than those who languish on the islands, glued to lands that do not properly belong to them. That will never belong to them. Every island, in fact, has kept its Carib name, and that is why they continue to belong to the first peoples who lived there, even if those peoples have been massacred to the very last one of them. We will be eternal tenants there, which explains why we can feel at ease, like Blaise, in any part of the vast world. Without any home countries of our own, the universe has become ours. (303)

The tinkerwomen represent a particular geopolitical solidarity with the peoples of the Caribbean and an anthropological (or perhaps Creole) solidarity with the non-Caribbean societies that have been subjected to similar processes of colonization and/or Creolization. Because of them, the Antilles no longer seem like a

6 "fille d'aucune terre, d'aucune de ces îles que se disputent depuis des siècles Espagnols, Anglais, Français, Hollandais, Danois, Suédois, Américains.”

7 "nous les pacotilleuses, femmes de vagabondages marin, bien plus en tout cas que ceux qui croupissent dans les îles, rivés à des terres qui ne leur appartiennent pas en propre. Qui ne leur appartiendront jamais. Chaque île, en effet, a conservé son nom caraïbe et c'est pourquoi elle continue d'appartenir au premier peuple qui l'a habitée quand bien même il a été massacré jusqu'au dernier. Nous y demeurons d'éternels locataires, ce qui explique pourquoi nous pouvons nous sentir à l'aise comme Blaise dans n'importe quelle partie du vaste monde. Privés de nos patries d'origines, l'univers est devenu le nôtre." 
site of dispersal but, instead, like a place where in future that which was dispersed can be brought together and connected (Ette, Literature on the Move 256).

While the function of the island in the nineteenth century was primarily based on isolation and exoticism, archipelagic thinking was consistently relational (König, "Édouard Glissants pensée archipélique”). Thus, Martinique, which is at the center of the novel, is part of an alliance of islands that derives its coherence from particular linguistic and cultural communicative "trans-processes." In the novel, the creation of the archipelagic system becomes a model of boundary-lessness, a metaphor for the overcoming of closed national boundaries (Ludwig and Röseberg 9). ${ }^{8}$ In his Traité du Tout-monde (Whole-world treatise), on the other hand, Édouard Glissant defines "archipelagic thinking”:

Archipelagic thinking suits the pace of our worlds. It borrows their ambiguity, fragility, derivativeness. ... It means fitting in with that part of the world that has, precisely, disseminated itself into archipelagoes, these kinds of diversities within the vastness, which nevertheless reunite riverbanks and marry horizons. We see what was continental and thick and weighed on us, in those sumptuous systematic thoughts that have ruled the history of the humanities to this day and which are no longer adequate to our explosions, to our stories, nor to our no-less-sumptuous wanderings. $(31)^{9}$

As Torsten König points out, given the diversity in which today's worlds present themselves and the varying courses taken by their histories, we must abandon the homogenizing discourses that have so far determined our view of world his-

8 Glissant himself describes the growing process by which the archipelagic system is created as follows: "What I see today is that the continents are increasingly turning into archipelagoes, at least as seen from the outside. The Americas are turning into archipelagoes, forming themselves into regions that transcend national frontiers. And I think that that is a term that needs to be restored to dignity, the term 'region.' Europe is turning into archipelagoes. The linguistic regions, the cultural regions, which go beyond national barriers, are islands, but open islands, that is the main condition of their survival." (“Ce que je vois aujourd'hui, c'est que les continents 's'archipélisent,' du moins du point de vue d'un regard extérieur. Les Amériques s'archipélisent, elles se constituent en régions par-dessus les frontières nationales. Et je crois que c'est un terme qu'il faut rétablir dans sa dignité, le terme de région. L'Europe s'archipélise. Les régions linguistiques, les régions culturelles, par-delà les barrières des nations, sont des îles, mais des îles ouvertes, c'est leur principale condition de survie.") (Glissant, Introduction à une poétique 44). 9 "La pensée archipélique convient à l'allure de nos mondes. Elle en emprunte l'ambigu, le fragile, le dérivé. ... C'est s'accorder à ce qui du monde s'est diffusé en archipels précisément, ces sortes de diversités dans l'étendue, qui pourtant rallient des rives et marient des horizons. Nous nous apercevons de ce qu'il y avait de continental, d'épais et qui pesait sur nous, dans les somptueuses pensées de système qui jusqu'à ce jour ont régi l'Histoire des humanités, et qui ne sont plus adéquates à nos éclatements, à nos histoires ni à nos non moins somptueuses errances." 
tory, which Glissant calls "continental." This is why the Martinican scholar calls the kind of thinking that is appropriate to today's world "archipelagic" thinking. He closes his Traité with an emphatic reference to "the thinking of the archipelago, of the archipelagoes” (la pensée de l'archipel, des archipels), conjuring up the overcoming of the old order (cf. König, "Édouard Glissants pensée archipélique" 117-118).

\section{VII.2.3 From the Static Concept of Exile, passing by the Black Atlantic to the In-Between}

A large part of the novel takes place in St. Pierre, in Martinique. Another important scene of action is Victor Hugo's residence in Paris. Almost the entire story takes place between Paris and Little Paris, where colonial society is depicted with its racial teachings and segregation, with its prejudices but also its zest for life, through carnival, sex, and poetry. It is also noteworthy that Halifax is often described as being the link between Europe and (French) America, because Adèle spends several years there. This positioning in the in-between seems to be symptomatic of the nineteenth-century Caribbean Creole upper classes. That inbetween, which is often referred to in postcolonial theory, finds its strongest expression in the sea as the central scene of action, the true connection between Europe, the Caribbean, and Africa. Céline says that she only feels comfortable when she is traveling, in other words on board ship. Here, the ship represents a kind of threshold: it can be seen as a vehicle that crosses the boundaries of time, transports the protagonist from one level to another, and thus makes possible an oscillation between regions defined by time and by space. Exile also plays an important role, as Céline notes: "The thing is that exile is our condition, for us Amerindian-Negro-White-Mulatto-Chabin-Indian-Chinese-Syrians of the archipelago. Exile created us" (Confiant, Adèle 59). ${ }^{10}$

Adèle's diary is also called "a journal of exile" (journal d'exil). Characteristically, however, there is also a critical engagement with the concept of exile: "Exile does not mean the same thing to Adèle as it does to me" (Le mot exil n'a pas le même sens pour Adèle et pour moi; 67-68). To Céline, exile is the condition of the native population. They do not necessarily like the sea itself, unless they are sailors or tinkerwomen. Céline's father hates the sea, because it swallows up souls. "The Atlantic is the world's largest cemetery" (L'Atlantique est

10 “C'est que l'exil est notre condition, à nous les Amérindiens-Nègres-Blancs-Mulâtres-Chabins-Indiens-Chinois-Syriens de L'Archipel. L'exil nous a créé.” 
le plus grand cimetière du monde; 60; cf. Gilroy, Black Atlantic). He was a former slave who had stayed with his master after slavery was abolished. For Adèle, exile is a test, a crucial ordeal. In Adèle's diary, which Céline reads while Adèle is asleep, she talks about her father's exile on Jersey and Guernsey.

"Exile," as a conventional concept having to do with migration, is critically examined, in its function as a stabilizer, per se, of a binary opposition between the center and the periphery. Confiant plays with the balance of power between colonial Europe and the colonized Caribbean. In the form of the relationship between Adèle and Céline, the Caribbean plays the role of the mother while Europe is the helpless and needy daughter. One can also see the whole as mutual affection. Céline desperately wants to have a daughter (and also calls Adèle "my daughter" [ma fille]), while Adèle sees a mother in Céline and soon confides in her:

And, you Negress, you have almost become a mother to me. You are the first person who has listened to me without judging me. You do not treat me like a madwoman, when I tell you about the love I feel for Albert Pinson. You understand me, you who have never eaten from a porcelain plate nor danced the minuet. You, Céline Alvarez Bàà! And like Bug Jargal making the sublime request to D’Auverney, the white colonist: “may I call you brother?” I claim you as my mother from now on. Yes ... (Confiant, Adèle 53) ${ }^{11}$

On Céline's first visit to Paris, it becomes clear that Hugo, as the master of the house, repeatedly and as a matter of course commands the services, including sexual services, of the women working in his house, and that that now includes Céline as well. He literally overpowers her. The following quotation, which can almost be read as a mockery of island theories, shows that Céline does not consider this rape and to a certain degree also enjoys it:

As soon as calm had returned, Hugo regained his usual energy, an amazing energy for a man on the threshold of old age. We went up to the attic, by a sort of tacit agreement, and he threw himself on my person and plowed my flesh, his eyes curiously closed. I let it happen, although I seldom felt pleasure. On the other hand, the sensation of being caught up by an unleashed wave, of being lifted up, rolled over, manipulated as though

11 "Et toi négresse, tu es devenue presque une mère pour moi. Tu es la première personne à m'écouter sans me juger. Tu ne me traites point de folle à lier lorsque je te parle de l'amour que j'éprouve pour Albert Pinson. Tu me comprends, toi qui n'as jamais mangé dans une assiette en porcelaine ni dansé le menuet. Toi, Céline Alvarez Bàà! Et comme Bug-Jargal adressant à D’Auverney, le colon blanc, cette requête sublime: 'puis-je t’appeler frère?,' je te réclame désormais pour mère. Oui ...” 
I weighed no more than a piece of straw, was very agreeable to me. I became an island, a small tropical island, being covered by powerful Europe with its enormous wing. (271) ${ }^{12}$

Here we see a representation of Europe's superior strength. Hugo calls Céline a little dove and would like, for his part, to be seen as a lion. But here, too, first appearances are deceptive, because Céline makes it clear that Hugo actually sees her instead as a bird of prey, as an eagle. In Michel Audibert, a mulatto poet who is Céline's lover, we see a certain competitiveness. Audibert had resented that Hugo had neglected to mention the uprisings in Martinique with even a word, and criticized him as a Negrophobe. This stereotyped representation is then brought to a head when the mulatto Audibert is confronted with the fact that Céline has been with Hugo, whereupon he breaks off contact with her. The colonial power relationship is displaced onto a competition over who is the better poet.

\section{VII.2.4 From Concepts of Identity to Questions of Conviviality}

Confiant continually creates situations in which beliefs of that time about the different races are made clear. It makes sense that in the nineteenth century, given the colonial constellations, the question of the conviviality of ethnic groups would be dealt with in a particularly intense way (see section I.5): Alexandre Verdet reads Count Gobineau's Essai sur l'inégalité des races humaines (Essay on the inequality of the human races). He forbids Céline and Adèle to share a room. Adèle recounts how Hugo himself would frighten her and her brother, when they misbehaved, by threatening to send them both to Bug Jargal. But she also tells Céline that since she was in Canada, she has had very different experiences, most of them positive, with black people. The fact that they have biblical names is seen as an implicit sign of how civilized they are. And Hugo and Verdet both dismantle their prejudices. Hugo also says that if he had known more about blacks before he wrote Bug-Jargal, that story would not have been written (Confiant, Adèle 276).

12 "Aussitôt le calme revenu, Hugo retrouvait son énergie habituelle, énergie étonnante pour un homme au seuil de la vieillesse. Nous montions au galetas, par une sorte d'accord tacite, et il se jetait sur ma personne, me labourait les chairs, les yeux curieusement clos. Je me laissais faire quoique j'éprouvai rarement du plaisir. La sensation d'être happée par une houle déchaînée, d'être soulevée, roulée, triturée comme si je ne pesais pas davantage qu'un fétu de paille, m'était par contre fort agréable. Je devenais une île, une petite île tropicale, que couvrait, de son aile immense, la puissante Europe.” 
Doctors Rufz and de Luppe, who work in the mental institution in Martinique, are openly racist: blacks cannot lose their mental facilities, because they have none to begin with (166). Henry de Montaigue makes an observation about the way that mulattos and blacks interact with each other in Martinique:

The hatred between the two races, though they rubbed elbows with each other daily, had taken me aback. It is not that I felt any particular affection for people of color, but those in Martinique seemed to me to be so well-regulated, so well molded into French culture, that I forgot their origins. And by the way, no one mentioned Africa! $(232)^{13}$

Adèle tells Céline about her father. He wrote his first book, Bug-Jargal, set in the West Indies, when he was sixteen. In it, he described the blacks, she says, as "strange creatures, having just barely left their animal state, bloodthirsty ... but endowed with a sense of cunning ... that was able to baffle European minds, too ensconced in cold reason, further magnified by Descartes" $(60-61) .{ }^{14}$ For Victor Hugo, she reports, the soul counts more than the intellect: "the sensations of the soul are a thousand times superior to the quibbles of the mind. ... There are invisible forces surrounding us-which we can approach by turning the tables." 15 Hugo believes that the blacks are the only race that does not close itself to these powers, and that that explains their victory over Napoleon's troops. Adèle was shocked to see a black man on the quay at Halifax who was able to speak perfect English (57-61).

While in earlier novels Confiant developed arguments for identity, such as the discourses of Créolité, which were never able to do without essentialist attributions, the nineteenth-century ethnic constellations shed light on historic connections that were never, not even then, reducible to pithy descriptions like "thoroughly racialized society." The historical representation of togetherness takes the place of an agenda. Thus, in his novel, Confiant completes the move away from a specific kind of concept of Caribbean identity to questions of conviviality. Unlike the other paradigm shifts staged within Caribbean research that I have presented here, such as the development of the archipelagic model, this

13 "La haine entre les deux races, qui pourtant se côtoyaient journellement, m'avait interloqués. Ce n'est pas que j'éprouvai une affection particulière pour les gens de couleur, mais ceux de la Martinique me paraissaient si policés, si bien moulés dans la culture française, que j'en oubliais leur origine. D’ailleurs, personne n'évoquait l'Afrique!'

14 "des créatures étranges, à peine sortis de l'animalité, sanguinaires ... mais dotés d'un sens de la ruse ... qui pouvait dérouter les esprits européens trop engoncés dans la froide raison magnifiée par Descartes.”

15 "les sensations de l'âme sont mille fois supérieures aux arguties de l'esprit. ... Des forces invisibles nous entourent-que nous pouvons approcher en faisant tourner les tables.” 
one has less of a theoretical foundation, but nevertheless the latent presence of the theme of conviviality can be seen as a symptom that the knowledge of conviviality (Ette, ZusammenLebensWissen) will prevail as a theoretical paradigm; I discuss this further in section VIII.1.

\section{VII.2.5 Themes within Caribbean Research, or from Créolité to the Tout-monde}

In Adèle, Raphaël Confiant takes up the Caribbean research theme in which the Caribbean is interpreted as a "laboratory of modernity," which is not just the object of European theorization but has made an important name for itself globally with the production of cultural theories.

The novel certainly displays some similarities with the genre of the new historical novel: there is no longer any literary construction involving a cyclical chronology and mythical elements set up as an alternative to the linear chronology of the European understanding of history. The filters of subjectivity and a personal presentation are explicitly reflected by the narrator. Confiant illustrates that history can in fact only be subjective, that it is for a subject that receives and narrates it. In the course of this self-reflection, historical philosophical preconditions such as continuity, progression, and teleology are unmasked as constructions. In a way that is symptomatic of the shift towards the modern in literary studies and the humanities, many narrated stories, coexisting with no claim to absolute truth, take the place of one universal history. The focus on questions of the circulation of knowledge and different transfer processes distracts us from the question of history and memory. In contrast to the classic new historical novel, here the nineteenth century is revalued as a background to current debates, since it is not so much that the representational nature of history is being problematized on a metalevel as it is that the historiographically established relationalities are being transformed. The novel is inscribed into the long-established transnational turn.

Writing in the in-between; the tinkerwoman as an exemplary bearer of subversive knowledge; relationality; the archipelagic model: what these paradigms have in common is breaking free of the concentration on constructions of identity and opening up the Caribbean, as a case study of a "testing of conviviality" (cf. Ette, ZusammenLebensWissen), to universal dimensions. It is no longer a question of exposing constructions of identity as essentialist but of declaring questions of identity per se to be obsolete. In Adèle et la pacotilleuse, Raphaël Confiant offers us a reversion to an earlier phase of accelerated globalization in order to show that many of the phenomena that we consider to be characteristic of our present time began much earlier than we assume. 
It is no surprise that he plays with the concepts so easily; after all, as a literary theorist, he has a particular kind of access to these topics. But this brings up the question of his audience's expectations and his own orientation towards that audience. While the discourses of Latin American literature's Boom movement and magic realism, which fulfilled a particular kind of expectation having to do with the exotic and with themes specific to Latin America, were rejected, at the very latest, by the Crack and McOndo movements and their manifestos, French-speaking Caribbean writers of the present and of this phase, on the other hand, are attuned to expectations having to do with the production of theory that originates in the Caribbean, with representatives such as Confiant and Glissant, but is open in a universal way. Thus, Confiant subjects his earlier Éloge de la Créolité (In Praise of Creoleness) to a critical retrospective review. But what is there to offer instead? Glissant calls his alternative model Tout-monde (the all-world). He takes as his guiding concept a view of the world that substitutes a positive understanding of chaos for the negative tendencies of globalization; this positive chaos model creates non-hierarchical relationships between the elements of its diversity in a network that is not fixed but consists of an ongoing process.

The Tout-monde is the whirling movement by which cultures, peoples, individuals, notions, aesthetics, sensibilities, etc. are perpetually changing through their connections with each other. It is this whirlwind. ... Because when you say a conception of the world, it is an a priori that gives the world an axis and a goal. The Tout-monde is a conception of the world without an axis and without a goal, with nothing but the idea of the whirling, necessary, and irrepressible proliferation of all of these contacts, all of these changes, all of these exchanges. (Glissant, “À propos de Tout-Monde,” cited in Ludwig and Röseberg 10) ${ }^{16}$

Adèle et la pacotilleuse provides a consistent implementation of the concept of creolization or of the Tout-monde that Glissant formulated. The literature is ahead of its own theory: on the theoretical level, Confiant continues to insist on the old concept of Créolité, albeit with modifications, but in his literary work he implements all of the theoretical paradigm shifts. The novel's first sentence provides a fitting conclusion:

16 "Le Tout-monde, c'est le mouvement tourbillant par lequel changent perpétuellement-en se mettant en rapport les uns avec les autres-les cultures, les peuples, les individus, les notions, les esthétiques, les sensibilités etc. C'est ce tourbillant. ... Parce que quand on dit une conception du monde, c'est un a priori qui donne au monde un axe et une visée. Le Tout-monde, c'est la conception du monde sans axe et sans visée, avec seulement l'idée de la prolifération tourbillante, nécessaire et irrépressible, de tous ces contacts, de tous ces changements, de tous ces échanges.” 
It is not true that all it takes to hear the rumors of the archipelago is to hold a pearly pink queen conch shell to your ear. All you will hear are indecipherable musics and unappeased sufferings. They spring from the all-world, from the African Guinea, forever lost, from Europe, the merciless lookout that never stops sneering with its great haughtiness. Other lands as well, whose names I have difficulty pronouncing and whose vastness I have difficulty imagining. (Confiant, Adèle 13; cf. also Ludwig and Röseberg) ${ }^{17}$

\section{VII.3 Khal Torabully}

One of the most important voices addressing cultural theory concepts from the Caribbean and engaged in developing them further is that of Khal Torabully, a poet, filmmaker, and cultural theoretician who was born in Port Louis, Mauritius, in 1956 and now lives mostly in France (cf. Bragard). ${ }^{18}$ His concept of "coolitude" builds on Glissant's work but critiques the lack of any Indian perspective in that work; coolitude has a transoceanic orientation. Whether in the islands of the Indian Ocean or those of the Caribbean, the importation of Indian contract workers as an alternative to slavery created a worldwide Indian diaspora, starting in 1830, that revealed its own mechanisms of acculturation and transculturation, because this "population with an ancient culture" refers to people who are both "Creoles and Indians" (Glissant, Kultur und Identität 41; emphasis in the original; see also Müller and Ueckmann, "Einleitung” 16). Torabully started developing his coolitude project in the 1980s. It is a poetic and poetological attempt to develop a vision and a revision of historical and current globalization processes based on the inclusion of what history has excluded, trying to give voice, as living subjects, to all of those who were forced to hire themselves out as wage and contract workers, usually under miserable circumstances, the world over (cf. Ette, TransArea 291).

The coolitude project not only created a literary monument and a memorial site for the coolies-who were primarily from India but also from China and other countries-but also developed a poetics of global migration, as expressed in Torabully's Cale d'étoiles, Coolitude (Stardock, Coolitude), published in 1992:

17 "Il n'est pas vrai qu'il suffit de porter à l'oreille une conque de lambi au rose nacré pour entendre les rumeurs de l'Archipel. On n'y perçoit que musiques indéchiffrables et douleurs inapaisées. Celles-ci jaillissent du Tout-Monde, de l'Afrique-Guinée à jamais perdue, de l'Europe, implacable vigie qui n'a de cesse de ricaner avec tant et tellement de hautaineté. D'autres terres aussi dont j'ai peine à prononcer les noms et à imaginer l'étendue."

18 Except for some small changes, the following observations are taken from Abel and Müller, "Cultural Forms of Representation of "Coolies”; Abel and Müller, "Korallen: Migration und Transozeanität.” 
Coolitude to lay the first stone of my memory of all memory, my language of all languages, my share of the uncharted that many bodies and many stories have often deposited in my genes and my islands. ... Here is my love song to the sea and to travel, the odyssey that my marine peoples have not yet written. ... My crew will be among the number of those who erase frontiers in order to enlarge the Country of Man. (Torabully, Cale d'étoiles 7) ${ }^{19}$

The crucial thing for Torabully is that he is not concerned just with the memory of certain forms of the most brutal exploitation, but also with a relationality that has become historical and that, in the process of intersecting migrational movements, creates a particular space:

You from Goa, from Pondicherry, from Chandannager, from / Cocane, from Delhi, from Surat, from London, from Shanghai, / from Lorient, from Saint-Malo, peoples of all the boats / that brought me towards another me, my dock of stars / is my travel plan, my zone, my vision of / the ocean that we all cross, even though we do not / see the stars from the same angle. // When I say coolie, I also say navigator without any / logbook; I say every man who has set off towards the horizon / of his dream, whatever boat he docked or / was supposed to dock. Because when you cross the ocean to be born / elsewhere, the sailor of a voyage with no return likes to plunge back / into his stories, his legends, and his dreams. For the time of an absence of memory. (Torabully, Cale d'étoiles 89, cited in Ette, TransArea 292) ${ }^{20}$

Significantly, Torabully makes a point never to think of the concept of the coolie in an exclusionary way. Instead, it is used figuratively, to illuminate specific phenomena of a globalization "from below," a globalization of the migrants who cross oceans in search of work. In a lyrical compression, this becomes a worldwide network of all those "travelers" who, as the objects of extreme exploitation, bind together the islands and cities of India, China, and Oceania with Europe's colonial ports (cf. Ette, TransArea 293).

19 “Coolitude pour poser la première pierre de ma mémoire de toute mémoire, ma langue de toutes les langues, ma part d'inconnu que de nombreux corps et de nombreuses histoires ont souvent déposée dans mes gènes et mes îles. ... Voici mon chant d'amour à la mer et au voyage, l'odyssée que mes peuples marins n'ont pas encore écrite. ... Mon équipage sera au nombre de ceux qui effacent les frontières pour agrandir le Pays de l'Homme."

20 "Vous de Goa, de Pondicheri, de Chandernagor, de / Cocane, de Delhi, de Surat, de Londres, de Shangai, / de Lorient, de Saint-Malo, peuples de tous les bateaux / qui m'emmenèrent vers un autre moi, ma cale d'étoiles / est mon plan de voyage, mon aire, ma vision de / l'océan que nous traversons tous, bien que nous ne / vissions pas les étoiles du même angle. // En disant coolie, je dis aussi tout navigateur sans / registre de bord; je dis tout homme parti vers l'horizon / de son rêve, quel que soit le bateau qu'il accosta ou / dût accoster. Car quand on franchit l'océan pour naître / ailleurs, le marin d'un voyage sans retour aime replonger / dans ses histoires, ses légendes, et ses rêves. Le temps d'une absence de mémoire.” 


\section{VII.3.1 Coolitude: Migration and Transoceanism}

Torabully's inclusion of the ethnic complexity of post-abolitionist societies in the Caribbean and the Indian Ocean makes it possible to conceive of the process of creolization in a less essentialist way. With his coolitude concept, he extends such French-Caribbean-marked models of archipelagic creolism as négritude, Créolité, Antillanité, and creolization, as well as Indianism and Indianoceanism (cf. Carter and Torabully 5-7, 16). Coolitude does not derive from geographical belonging or ethnic origin but rather from the economic and legal situation of the coolies, contract workers who came from India, China, Europe, and Africa to work in various archipelagic regions such as the Caribbean, the Indian Ocean, and the Pacific. In his mosaic model of composite identities, Torabully introduces social status as the theoretically decisive factor in creolization (see Abel, “Orientalische Dopplungen").

In his foundational poetic texts Cale d'étoiles, Coolitude (Stardock, Coolitude, 1992) and Chair corail: fragments coolies (Coral flesh, coolie fragments, 1999), Torabully established the theoretical premises of coolitude. But coolitude first attained an international reception and dissemination through the volume that Torabully put together with the historian Marina Carter: Coolitude: An Anthology of the Indian Labour Diaspora (2002). This volume is a collection in multiple ways. It unites Khal Torabully's own poetry on worldwide Indian labor migration with a literary-historical anthology of the poetry and prose of Indian diaspora writers, going back to the mid-nineteenth century, especially in the Indian Ocean-Mauritius (beginning in 1843), Fiji, Java, Goa (1860-1870)-but also in the Americas-Trinidad, Guiana, Suriname, Guadeloupe, and Martinique, starting in 1846. In addition, it represents a monograph on the theory and poetics of coolitude. Formally, it is a mixture of a historical anthology in the narrower sense, a workbook including short definitions, and a theoretical positioning of coolitude in the form of interviews by the authors. Through the hybridity of its textual format, Coolitude offers both an academic interpretation of and artistic access to the world of the Indian diaspora by recounting "the essence, or the essences" (Carter and Torabully 148) of the colonial Indian diaspora and deconstructing traditional conceptions from the British empire, using previously unpublished texts including poems and dramatic pieces.

There follows a situating of the theoretical genesis of the concept among a series of theoreticians of creolization and relationality, including Glissant, Deleuze and Guattari, Confiant, Bernabé and Chamoiseau, and Benoist; then, the development of one of the key themes of coolitude, namely the coolie odyssey, the taboo ocean crossing from the Indian subcontinent, is traced. After that, there is a look at the cultural-theoretical aspects of the perception of the 
Other, such as the tripled stigmatization of coolies and the experience of contract work. The three models that Torabully and Carter have identified as marking coolies as Other and trapping them in their role as victims are, first, the mystery of the Orient; second, the barbarian invader; and third, the "ambassador of exoticism and sensuality" (187-188). The closing reflections are dedicated to the coolie legacy and consider the memorial politics of the Indian diaspora in the nineteenth and twentieth centuries. Before the anthology ends, with a conclusion called "Revoicing the Coolie" and a collection of Torabully's own prose and poetry, it incorporates a long theoretical section that explains important "Theoretical Premises of Coolitude" in the form of a conversation. The first part addresses the relationships among "Césaire, Négritude and Coolitude" (143-159). The second part stakes out "Elements of the Coolie’s Memory" (160-165). In the third part of the interview, aesthetics and literature come into play (165-189), while the fourth section deals with "Tradition, Society and Indianness" (190-194). The fifth section, which is concretely poetological, tries to define "Some Literary Characteristics of Coolitude" (195-213).

The Belgian theorist Véronique Bragard, who continued the theoretical reception of coolitude with her Transoceanic Dialogues. Coolitude in Caribbean and Indian Ocean Literatures (2008), pointed out, as an important poetological characteristic, that what was at the center of coolitude was not the coolie per se but rather the nightmarish transoceanic voyage, both as a historical migration and as a metonym for cultural encounters (Carter und Torabully 15). The literary focus therefore always returns to the sea voyage, as an element that destroys and continually reconstructs identity. The voyage thus becomes an incision, displacing the loss of the homeland from the center of diasporic identities. On a more abstract level, the voyage thereby connects with a suppressed meta-memory of diasporic island identities in general, building human bridges, or so-called hommes-ponts, who in turn become the interpreters of the world's cultures within their respective island microcosms (Turcotte und Brabant 1983, cited in Carter und Torabully 216).

Torabully's particular contribution to the figure of the transoceanic journey now refers to a poetics of the "Indian Element" (148). The trauma of the ocean crossing takes on a special status in the Indian context, because of the Kala Pani taboo, the taboo against the evil black waters, referring to the leveling of caste differences in the threshold situation that the ship represents. These psychosocial aspects of the ocean trauma are picked up linguistically in coolitude and characterize its particular aesthetic. 


\section{VII.3.2 The Maritime Symbolism of the Coral}

A further aesthetic circumstance, arising from the focus on the ocean voyage, is the search for maritime symbols. The central image of coolitude is therefore the metaphor of coral flesh (chair corail), which stands for hybrid relationalities in the island cultures: "No longer the Hindu man of Calcutta // But coral flesh of the Antilles" (Torabully, Chair corail 108). ${ }^{21}$

The coral metaphor is not unlike the mangrove and rhizome images of Créolité, but formulated transoceanically. As a symbol for the fluidity of relationships and influences, it uses the coral's properties as an intermediate entity, a creature between stone and animal, that only appears in the sea, and mostly in the tropical belt. Thus, the coral represents archipelagic thinking, in the sense of Glissant's ambiguous thinking (pensée de l'ambigu), as well as the porousness of various currents. The coral's characteristic spiral shapes, its circumvolutions, are connected to visualizations of the fractal logics in processes of creolization. Thus, coolitude turns out to be related not just theoretically but also aesthetically to Glissant and the Créolité writers, who also consider diasporic identities to be not static and fixed but rather subjected to the ongoing interplay of history, culture, and power (Carter und Torabully 11).

Unlike the rhizome, however, which lives under the earth, the coral can be observed in its living habitat. In addition, it allows for an agglutinating connectedness which is built out of layering, consolidation, and sedimentation, like a palimpsest; this is not just an erratic connectedness but it maintains the egalitarian aspect of connection because it is open to all currents. The very nature of the coral is hybrid, because it is born out of the symbiosis of phytoplankton and zooplankton. For a metaphor of diversity, nothing could be better. The coral is root, polyp, and flattening; it is a form that changes on its own, pliable and hard, dead and alive, and even varied in color. Although it is rooted, it releases the world's largest migration, that of plankton, which can be seen from the moon, like the Great Barrier Reef, a coral archipelago that was named to UNESCO's World Heritage list and is simply the most broadly spread out living sculpture on earth (Torabully, "Quand les Indes” 70; cf. Ette, TransArea 295).

In addition to coolitude's "maritime spirit" (Carter and Torabully 158), however, it also has more static visualization components that rely not on dynamic three-dimensional models but on structures of two-dimensional composition, such as the mosaic, in which Creole Indian tiles complete the overall picture of creolization, but it is not the idea of the melting pot that is central. Torabully

21 "Non plus l'homme hindou de Calcutta // Mais chairs corail des Antilles.” 
sometimes also translates the composite pieces of the mosaic into three-dimensionality in the form of individual roots of the rhizome (Carter and Torabully 152). Even in the coral metaphor, however, the idea of the stone, of that which is solid, does not disappear, and it always leads back to the Césaire-related founding moment of coolitude. Torabully's appeal to négritude and to Antillanité, which is understood as négritude's direct heir, are therefore indispensable for an understanding of the theoretical positioning of coolitude. A deep empathy with Aimé Césaire, the founder of the Franco-Caribbean négritude movement, and a 1997 conversation with him in Fort-de-France, Martinique, about the legacy of négritude and its continuation in coolitude, are part of the founding myth of this concept of creolization.

The connection between the two theories involves two ideas: the reconciliation of the "descendants of the oppressed" (Carter und Torabully 172), which understands itself as contributing to the processing of the historical tensions between the legacy of Atlantic slavery and the legacy of the coolies in Creole societies; and the idea of a conceptual bridging or redefinition. The theoretical limits of négritude, which, because of its demand for and recognition of a "black" identity, is seen as being inadequate to the ethnic complexity of postslavery creolized societies, are thus transcended by the coolitude model. In several places, Carter and Torabully argue that coolitude is not just an Indian version of négritude. First of all, it is not an ethnic or essentialist category (150, 153), and secondly, its focus on the crossing means that neither a mythical origin nor exile itself is thematized but identity is instead dissolved in permeability. Négritude and coolitude share a discursive reclassification of stigmatized colonial alterities; they part ways over the issue of the recognition of the cultural influence that contract migration from India had on some modern societies around the world, societies that it either decisively shaped, such as Mauritius, Trinidad, Guiana, and Fiji, or on which it at least left a mark, such as Guadeloupe, Martinique, and eastern and southern Africa.

Coolitude represents a spatial understanding that not only emphasizes an internal archipelagic relationality in the manifold communications between islands and archipelagoes but also draws attention to the dynamics of an external relationality (Ette, TransArea 40). Coolitude thus becomes the model of a spatial history, which is always a history of movement: the forced deportations of enslaved peoples as well as Indian contract workers show that internal and external relationalities must be connected in order to comprehend spaces in a complete and holistic way. 


\section{VII.4 J.-M.G. Le Clézio, Édouard Glissant, and Epeli Hau’Ofa: Avant-Gardes in Oceania}

The previous reflections on paradigm shifts in Caribbean research and in narrative stagings of the same bring up the question: is there such a thing as a Creole, archipelagic, or transoceanic avant-garde? ${ }^{22}$ In fact, a group of writers has recently spoken up, including the three writers J.-M.G. Le Clézio, Édouard Glissant, and Epeli Hau'Ofa. For these authors, Oceania is a crucially significant cultural space, and in their work they take up, in an innovative way, concepts that are important for Caribbean theorization. In his poetological treatise La cohée du Lamentin (2005), Édouard Glissant writes:

\footnotetext{
In truth, what [Wilfredo Lam] confirms, whether with Picasso, the Surrealists, or Césaire, is the organic and historic convergence of these revolutions in sensibility. It is "modern" with Picasso and "African" with Césaire, because the poetics of their universes address the same archipelagoes of excess, of revolt, and of convulsive beauty that André Breton and his friends, for other reasons, sensible or foolish, also frequent. $(182)^{23}$
}

These words illustrate on the one hand what a central point of reference the avant-gardes represented for Caribbean intellectuals talking about cultural theory and, on the other, that in their reception there has always been a tension between the European and the non-European.

In fact, the avant-gardes, and especially their second phase, that is to say from the nineteen-fifties to the early nineteen-seventies, did constitute a key reference point for many intellectuals from postcolonial constellations. Given the per se non-European dimension of the historical Breton-centered avant-garde, their attraction for precisely non-European writers, which also always involves a provocation, makes sense. Thus, it is not surprising that Glissant feels it necessary to process his intellectual father, Aimé Césaire, who as the representative of négritude was in close contact with André Breton. But what are the dynamics that determine the specifically non-European avant-gardes? With reference to Hal Foster, Geeta Kapur writes, "if the avant-garde is a historically conditioned phenomenon and emerges only in a moment of real political disjuncture, it will appear in various forms in different parts of the world at different times"

22 With regard to the following remarks, see Müller, "J.-M.G. Le Clézio."

23 "En réalité, ce que [Wilfredo Lam] vérifie avec Picasso comme avec les Surréalistes ou avec Césaire, c'est la convergence organique autant qu'historique de ces révolutions de la sensibilité. Il est 'moderne' avec Picasso et 'africain' avec Césaire, parce que les poétiques de leurs univers abordent aux mêmes archipels de la démesure, de la révolte et de la beauté convulsive que fréquentent, pour d'autres raisons ou déraisons, André Breton et ses amis.” 
(Kapur 374). The Nigerian writer and curator Okwui Enwezor expressed himself in a similarly provocative way in a contribution to the Documenta 11 catalogue:

\begin{abstract}
What, then, is the fate of the avant-garde in this climate of incessant assault upon its former conclusions? ... While strong revolutionary claims have been made for the avant-garde within Westernism, its vision of modernity remains surprisingly conservative and formal. ... The propagators of the avant-garde have done little to constitute a space of self-reflexivity that can understand new relations of artistic modernity not founded on Westernism. (Enwezor 46)
\end{abstract}

I would now like to look at two representatives of French-speaking constellations, namely Édouard Glissant and Jean-Marie Gustave Le Clézio. Glissant was from Martinique and lived for a long time in France and in the United States; Le Clezió, though he was born in Nice, had family roots in Mauritius and indeed grew up there. Both of them, in terms of their biographies as well as in the way they publicly positioned themselves as writers, belonged to the second phase of the historical avant-garde project ${ }^{24}$; they went through various stages of boundary drawing and in 2006, in a common project that I call the "oceanic turn," they chose new emphases that, although they were not explicitly called avantgarde, nevertheless implicitly corresponded to two established criteria for the avant-garde: first, the dissolution of the line separating art and life, and secondly, the group character of the avant-garde project. My thesis is that non-European, and at the moment, specifically, oceanic positionings have the particular potential to produce alternative avant-garde projects still today, because the tension that is inherent to their writing, with respect to colonial dimensions at the time of the historical avant-gardes, creates a productive dialectic, over the long term, at different phases of differentiation.

After we take a quick look at the first phase of Le Clézio's and Glissant's avant-gardist positions, I want to then look briefly at a Creole current in which Le Clézio and Glissant are not the main players but with which they are nevertheless closely connected and which is key to understanding their later development: the Créolité discourses of the Martinican novelists and cultural theorists Raphaël Confiant, Jean Bernabé, and Patrick Chamoiseau, who can be counted as the intellectual sons of their mentor Glissant. At the end of the nineteen-eighties, these three writers produced a manifesto that not only offered an answer to the urgent question of a Caribbean aesthetics but was also clearly avant-gardist. This current is then in turn followed by a reaction from Glissant and Le Clézio, the erstwhile mentors of the advocates of Créolité; Glissant and Le Clézio issue a

24 On the project character of the avant-garde, see Asholt. 
plea for a transoceanic identity. With respect to this third phase, finally, extracts from the work of the Fijian essayist Epeli Hau'Ofa will show that the networked character of the avant-garde project is particularly significant for a transoceanic continuation. The writers I highlight here also represent three different oceans: Hau'Ofa the Pacific, Le Clezió the Indian Ocean, and Glissant the Atlantic.

\section{VII.4.1 Le Clézio und His Relationship to the Classic Avant-Gardes of the Nineteen-Fifties}

Too often, as well, this notion of culture is reduced to just the arts. Why should that be where culture is? In this life, everything is important. Rather than saying of a man that he is cultivated, I would rather that I were told: he is a man. (Le Clézio, L'extase matérielle $17)^{25}$

This is what Le Clézio writes in L'extase matérielle (Material ecstasy, 1959), the author's early theoretical manifesto in which he develops fundamental poetological ideas. Material ecstasy can be described as a form of a different condition (Rimpau 20). What is meant is a kind of pattern of religious experience in which, as in mysticism, the borders between spirit and matter and between self and world become fluid. It is about the attempt to relate the visible with the invisible and, ideally, to experience the transcendent through the world (21).

In her study of J.-M.G. Le Clézio, Laetitia Rimpau points out that the central theme in L'extase is the suffering of consciousness and the search for ways to avoid this suffering. Material ecstasy can be seen as a redemption myth: a form of metamorphosis-both punishing and liberating at the same time-in which a spiritual connection with basic forms of nonhuman existence is sought through a mimetic immersion. This is expressed, programmatically, as "one requires metamorphoses” (on oblige aux métamorphoses; Le Clézio, L'extase matérielle 246). With respect to this particular aspect, Rimpau aptly works out that this is about a voyage into the material world, which is both resistant and at the same time challenging. Materiality represents the experimental field that thinking is able to process and through which it can change itself (Rimpau 20). This aspiration of Le Clézio's to dissolve the boundary between art and life, along with his connection to the Tel Quel group, ties him very closely to the avant-gardes, although he makes no radical confession in that direction. His at-

25 "Trop souvent aussi, on réduit cette notion de culture au seul fait des arts. Pourquoi serait-ce là la culture? Dans cette vie, tout est important. Plutôt que de dire d'un homme qu'il est cultivé, je voudrais qu'on me dise: c'est un homme." 
titude is thus ambivalent; he only partially incorporates avant-gardist tendencies. This is particularly clear in the following passage:

In order to say of a man that he is civilized, we often use the word "cultivated." Why? What is this culture? Often, too often, it means that this man knows Greek or Latin, that he is able to recite poetry by heart, that he knows the names of Dutch painters and German musicians. In that case, culture is a way to shine in a world where futility is in order. This culture is nothing but the flip side of ignorance. Cultivated for this person, uneducated for that one. Being relative, culture is an infinite phenomenon; it can never be completed. What is he then, this cultivated man that they want to give us as a model? (Le Clézio, L'extase matérielle 22$)^{26}$

\section{VII.4.2 Glissant and Surrealism}

A dialectical relationship between independence, on the one hand, and influence from the European avant-garde project, on the other, appears to be constitutive of Glissant's integration into the second phase of the avant-gardes. In the late nineteen-fifties, Glissant follows Césaire quite closely and, after a certain period of conflict, reproaches him for only emulating the European avant-gardists, who, Glissant says, are not creating any literature but are only giving a new look to things that already exist.

Starting in the nineteen-forties, négritude slowly became a broader movement. From 1941 to 1945, Césaire published the journal Tropiques in Martinique. This journal made a point of presenting surrealism as a way for the Antillean, in particular, to be able to find a way back to his unconscious, buried, actual personality; in this, Césaire goes against the established order. ${ }^{27}$ Glissant, who as a student at the Lycée Schoelcher in Fort-de-France was under Césaire’s influence and who was later one of his most dedicated critics, affirms the tremendous significance and richness of Tropiques for Martinique's later literary development. On the one hand, the articles about modern French poetry are formative for Glissant (Ludwig 146). On the other hand, Chamoiseau has aptly summarized Glis-

26 'Pour dire d'un homme qu'il est civilisé, on dit souvent 'cultivé.' Pourquoi? Qu'est-ce que c'est que cette culture? Souvent, trop souvent, cela veut dire que cet homme sait le grec ou le latin, qu'il est capable de réciter des vers par cœur, qu'il connaît les noms des peintres hollandais et des musiciens allemands. La culture sert alors à briller dans un monde où la futilité est de mise. Cette culture n'est que l'envers d'une ignorance. Cultivé pour celui-ci, inculte pour celui-là. Étant relative, la culture est un phénomène infini; elle ne peut jamais être accomplie. Qu'est-il donc, cet homme cultivé que l'on veut nous donner pour modèle?”

27 Ralph Ludwig's research laid an important foundation for my observations on Créolité in the following. See Ludwig 106. 
sant's role as the antithesis in literary development, as the conqueror of négritude.

Between 1950 and 1970, Glissant and Le Clézio both engaged vigorously with prominent representatives of the avant-garde, including the Tel Quel group and Aimé Césaire. Both of them participated in the avant-garde movement to some degree, but not consistently. They are paradigmatic of Luhmann's oft-cited dictum that the avant-garde only articulated the problem and shaped it. But now we have to observe how the art world deals with this problem that it has set for itself (see Magerski 99). In Le Clézio's case, this occurs in a question about art and life, and in Glissant's case through the attempt to stage an otherness without falling back into essentialisms.

\title{
VII.4.3 Creolization as an Avant-Garde
}

\begin{abstract}
We are no longer afraid ... to inhabit the French language in a Creole way; we are not talking about decorating it with little Creole words to create a kind of folkloristic and regionalist French, that is not at all what we mean. What we are talking about is recuperating all of the rhetoric of the Creole language and trying to graft it through French linguistic material. (Chamoiseau and Confiant, "En guise d'introduction” 14; cf. Ludwig 146) ${ }^{28}$
\end{abstract}

This is the Martinican writer Raphaël Confiant, in an interview with Ralph Ludwig and Ottmar Ette. In his analysis, Ralph Ludwig makes it clear that Confiant's statement means that the act of resisting the cultural assimilation of the Antilles -an act that represents an important stimulant for Antillean literary debate-is connected not to the semantic but rather to the aesthetic plane. On the linguistic level, it is clear that the success of the literary language that is thus described may well have consequences for standard French. As the great literary prizes go to literary texts written in a French that is shot through with oral Creole, thus introducing them into a newly contoured canon whose traditional form was always the basis of proper written French (the bon usage), this orally influenced French-language literature is also shaking up the conventional standard for prestige (Ludwig 146).

In the same interview, Patrick Chamoiseau says:

28 "Nous n'avons plus peur ... d'habiter la langue française de manière créole; non pas de la décorer avec des petits mots créoles pour créer une espèce de français folklorique et régionaliste, il ne s'agit pas du tout de cela. Il s'agit de récupérer toute la rhétorique de la langue créole et d'essayer de la greffer à travers un matériau linguistique français.” Concerning the following remarks see also Müller and Ueckmann, "Einleitung” $18 \mathrm{ff}$. 
We have a Creole imaginary that is our own, but which has been suppressed, and without which we cannot exist. This work of recuperating Creole culture is done, among other places, in the novel. This recuperation of Creole culture has a necessarily historical coloring, and that is why many of our novels are also historical explorations, because we cannot try to reinvest the times and the cultural moments of our vision of the world if we do not include themes that have a profound resonance in our substance, in our imaginary. (Chamoiseau and Confiant, "En guise d'introduction" 14$)^{29}$

In his novel Le Nègre et l'Amiral (The Negro and the admiral, 1988), Confiant deals with the period from 1939 to 1945, when Martinique was cut off from the outside world. In it, the avant-garde project experiences a mise-en-abîme, with the appearance of Claude-Lévi Strauss, the Russian revolutionary Victor Serge, und André Breton. With his own particular brand of irony, Confiant shows Breton discovering the journal Tropiques (Confiant, Le Nègre et l'Amiral 98-99; cf. Ludwig 147).

In their Éloge de la créolité (1989), Chamoiseau and Confiant, along with the linguist Jean Bernabé, define their fundamental theoretical positions (cf. Ludwig 148). Créolité is based on the historical reality that established Antillean society: the forced contact between cultures. In this respect, the Antilles went through a process that is now increasingly shaping the world: "The world is entering a state of Créolité" (Le monde va en état de créolité; Bernabé, Chamoiseau, and Confiant 52; cf. Ludwig 148). Ludwig points out that to begin with, Créolité has exemplary anthropological value because the kind of patchwork identity that ends in Créolité is the appropriate way towards (post-)modern self-discovery (Ludwig 148). But the primary goal of Créolité has to do with the Creole societies of the Antilles themselves and includes the appreciation and preservation of the collective oral memory. This act is not an exclusively semantic one but extends into the macro- and microstructure of literary texts; this is the only way to achieve what Confiant and Chamoiseau call a Creole rhetoric (Ludwig 149).

Compared to Le Clézio's and Glissant's early forms of expression, the avantgardist Créolité project of Éloge de la créolité has a consistent agenda: the group expresses itself as a vanguard in the classical sense and leaves no doubt about its ambiguity. There is a very obvious imbalance that appears here: while the Eu-

29 "Nous avons un imaginaire créole qui nous appartient, mais qui a été refoulé, et sans lequel nous ne pouvons pas exister. Ce travail de récupération de la culture créole se fait, entre autres, dans le roman. Cette récupération de la culture créole a nécessairement une coloration historique, et c'est pourquoi beaucoup de nos romans sont aussi des explorations historiques, parce qu'on ne peut pas tenter de réinvestir des temps, des moments culturels de notre vision du monde si on n'inclue pas des thématiques ayant des résonances profondes dans notre fond sensible, dans notre imaginaire." 
ropean avant-gardes incorporate non-European cultures, the non-European and anticolonial avant-gardes appropriate European culture, but with a critical stance. The ever-present asymmetry of the avant-garde, which the Creole writers note and critique so strongly, leads to the question of whether an avant-garde position is in fact only possible in the first place from the point of view of an imperial understanding.

\section{VII.4.4 Transoceanism as an Avant-Garde}

Critics have claimed that the representatives of Créolité failed, in the end, to capture ethnic difference without falling back into essentialisms (Mignolo, Local Histories/Global Designs 241-242). As a result, there has been some discussion about basic principles and some further development: as already mentioned in this volume, since the turn of the millennium, new positions have been established, among which Glissant's Introduction à une poétique du divers (Introduction to a poetics of variety) has met with a particularly strong resonance. In it, Glissant drafts the alternative model of "archipelization" and describes the whole world as being in a process of creolization and archipelization. The last and most comprehensive step in Glissant's thinking is then the Tout-monde, the all-world (cf. Ludwig and Röseberg 9) ${ }^{30}$ that we have already discussed, in which non-hierarchical relationships among the elements of variety are recognized in an ongoing process. Put more abstractly, and expanded into a societal model, the Tout-monde implies a rejection of one-dimensionality, of a hierarchically structured understanding of culture, of a closed and inflexible social order $(9,10)$. A consistent understanding of the Tout-monde also implies that the various "media implementations" of communicative and aesthetic expression, such as literature, poetry, music, and the visual arts, cannot be separated from each other (10). Although the Tout-monde has the potential to function as an avantgarde, it nevertheless requires an additional concretization of art: a few years before his death in 2011, Glissant began a radical project using life itself, called Les peuples de l'eau (The water peoples). Here, for the first time, art and life are united in an innovative way, giving the project an avant-garde character:

On July 27, 2004, under the auspices of UNESCO, the ship La Boudeuse set off from Bastia, in Corsica, under the command of Captain Patrice Franceschi, with twenty-four scientists

30 Ludwig and Röseberg refer to Beate Thill's translation and commentary in Glissant, Kultur und Identität 73. 
on board. After 1063 days and having traveled sixty thousand kilometers, the ship returned to Bastia on June 25, 2007.

There were twelve expeditions planned to visit eight populations that are only reachable by water because they live on secluded islands, river banks, or coasts: in other words, "peoples on the water." The expeditions took the team to the Yuhup in the Amazon; to Easter Island (aka Rapa Nui); to Fatu Hiva, the most remote of the Marquesas Islands; to Raga Island (Vanuatu), in Oceania; to the Buginese people on Sulawesi in Indonesia; and to the Badjao people who live between the Philippines and Indonesia. Twelve writers and journalists, chosen by Édouard Glissant, each took part in one of the expeditions; [these included] Alain Borer, Gérard Chaliand, Régis Debray, Patrick Chamoiseau, Jean-Claude Guillebaud, J.-M.G. Le Clézio, Federica Matta, Edwy Plenel, Antonio Tabucchi, and André Velter. ${ }^{31}$

\section{VII.4.5 Transoceanic Representations. Le Clézio, Raga; and Hau’Ofa, We Are the Ocean}

While Le Clézio advocated an inner voyage in his 1959 book L'extase matérielle, with his fictional travel journal Raga he staged a very concrete voyage: in a total of nine chapters, the Nobel Prize winner interwove several stories with historical, anthropological, and documentary references to Raga Island (in what was once the New Hebrides, now the Republic of Vanuatu). He begins with a short exposition on the early European expeditions to the Pacific, in search of the Australian continent, with its fabled treasures. He calls Oceania, with its many islands, an invisible continent that the Europeans neither could nor wanted to see. Raga is a part of the European colonization. After the historical excursus there follows a fictional story about the long trip that one family took in a boat across the sea, and about the family's arrival on Raga. The story combines some of the myths and legends of the Vanuatans. The author also reports on his own trip to

31 "Unter der Schirmherrschaft der UNESCO brach am 27. Juli 2004 das ... Segelschiff La Boudeuse unter dem Kapitän Patrice Franceschi mit 24 Wissenschaftlern an Bord von Bastia (Korsika) zu einer Weltumsegelung auf. Nach 1063 Tagen und 60.000 zurückgelegten Kilometern kehrte das Schiff am 25. Juni 2007 nach Bastia zurück.

Geplant waren zunächst zwölf Expeditionen zu acht Völkern, die nur vom Wasser aus erreichbar sind, da sie auf abgeschiedenen Inseln, an Flussufern oder an Küsten leben, also 'Völker am Wasser.' Die Expeditionen brachte die Mannschaft dann zu den Yuhup/Amazonas; zu den Osterinseln der Rapa Nui; nach Fata Hiva, der abgeschiedensten Marquesasinsel; auf die Insel Raga/ Vanuatu in Ozeanien; zu den Bugis der Celebes Inseln (Indonesien) und zum Jaranga-Archipel, wo die Badjaos zwischen den Philippinen und Indonesien leben. Zwölf Schriftsteller und Journalisten, ausgewählt von Édouard Glissant, nahmen jeweils an einer der Expeditionen teil[, darunter]: Alain Borer, Gérard Chaliand, Régis Debray, Patrick Chamoiseau, Jean-Claude Guillebaud, J.-M.G. Le Clézio, Federica Matta, Edwy Plenel, Antonio Tabucchi und André Velter." See the Wunderhorn Verlag's publishing program ("Völker am Wasser"). 
Raga, made on the invitation of Édouard Glissant, on board the three-masted ship La Boudeuse (described above). He tells of his encounters with the people there and of their stories, which deal with life, customs, and their confrontations with the Europeans. Le Clézio notices the traces of colonization, which can still be felt today: the islands have been drastically depopulated through imported diseases, slavery, and the caprice of the colonial powers. He mentions that after colonization ended, the people returned to their natural gardens, where the spirits lived, and that they stopped tending to the Europeans' plantations, which relied on clearing and monoculture, instead allowing them to become overgrown. Finally, he shows the many various forms of the island peoples' resistance to colonization, along with their consequences. That resistance expresses itself in the Creole language and, most of all, in music.

Le Clézio then leaves Raga, taking with him the stories and the impressions that the island and its people made on him. He hopes that all of Oceania, that "invisible continent," will some day have its freedom finally returned to it, and he analyzes the degree to which the recent history of Vanuatu has become a caricature. It is said that Bislama, the official language, is a patois, a dialect. By the time the West had taken hold of the archipelagoes of this ocean, it was already too late. The drums of Ambrym, of Efate, the conch shells of Tahiti were not enough to keep the intruders away who came in steel ships nor to ward off the motley crowds of people who followed them: settlers, tourists, pedophiles-fourteen-year-olds were married off to Gauguin and Fletcher-and, on top of those, missionaries, who wanted to root out the demons and clothe the inhabitants' nakedness (Le Clézio, Raga 92-93). The “paradise islands” became a hell for prisoners and prostitutes. Later, the Pacific became the battleground for a merciless war and then an open testing ground for nuclear weapons. Le Clézio asks, provocatively: Is this embarrassing for the French? Have these far-off archipelagoes not been a no-man's-land ever since they were first conquered? Did we not have every right to do whatever we wanted with them and with their inhabitants, shamelessly? Disunited, chopped into pieces, divided up among the colonial powers, the Pacific continent became invisible. A nonplace, inhabited by "savages," by former cannibals. Or, what amounts to the same thing, a Garden of Eden where everything existed in excess: flowers, fruits, women.

Given the critique of colonialism on the one hand and the emphasis on the relational dimension of transcolonial thinking, paired with fictional elements, on the other, Le Clézio's staging of Raga Island proves to be trans-archipelagic and represents a worldwide cultural model: a crossing and interpenetration of relationships among various archipelagoes that have entered into a reciprocal proc- 
ess of transformation. Epeli Hau'Ofa, from Fiji, also records this transoceanic dimension (see Müller and Ueckmann, “Einleitung” 28f.):

There is a world of difference between viewing the Pacific as "islands in a far sea" and as "a sea of islands.” The first emphasizes dry surfaces in a vast ocean far from the centres of power. Focussing in this way stresses the smallness and remoteness of the islands. The second is a more holistic perspective in which things are seen in the totality of their relationships. (Hau'Ofa, We Are the Ocean 22)

Hau'Ofa takes up Glissant's and Le Clézio's ideas and advocates a paradigm shift in how we see the Pacific by thinking of it through the relational dimension of a transoceanic space. The element of relationality has an existential character for every interpretation of Oceania, expressed as the paradigm of a "sea of islands" in contrast to the vision of many "islands in a far sea":

\begin{abstract}
Continental men, namely Europeans, on entering the Pacific after crossing huge expanses of ocean, introduced the view of "islands in a far sea." From this perspective the islands are tiny, isolated doors in a vast ocean. Later on, continental men-Europeans and Americansdrew imaginary lines across the sea, making the colonial boundaries that confined ocean peoples to tiny spaces for the first time. These boundaries today define the island states and territories of the Pacific. (ibid.)
\end{abstract}

Hau'Ofa implements Derek Walcott's dictum that “The sea is history.” In Hau'Ofa's manifesto We Are the Ocean, he argues for reclaiming the ocean as a significant cultural space. Like Le Clézio, he, too, refers to Glissant and the Peuples de l'eau project. Thus, a worldwide network of oceanic connections is created, connections that position themselves as avant-garde in that the outmoded idea of a manifesto is replaced with the radical staging of art as life: the sea voyage becomes text. This radicalism can only arise because Glissant and Le Clézio, its main proponents, displayed a certain ambivalence in their integration into the historical avant-gardes. The dialectical tension experiences a productive dissolution in a new avant-garde tension. The relational connection across the oceans becomes a constitutive element. What functions as a network on the spatial level can be understood as a project on the level of time (Asholt 97-120; Berg and Fähnders 14). The concept of the network is of course a product of the late twentieth century, the World Wide Web, and computer networks. But it is no coincidence that understanding the avant-garde as a network was and is not strange to the avant-garde itself (Berg and Fähnders 12).

In summary, we can say that the writers discussed here are representative of two epistemological turns: first, a trans-essentialist one, and second, a transterritorial one. The step of aggregating the two paradigm shifts is then crossed with the different respective roles as avant-garde movements. We have seen three dif- 
ferent variations of the avant-gardist dimension: 1 . ambivalent, in the early writings of Glissant and Le Clézio; 2. radical, that is to say consistently avant-garde, in the Créolité writers; and 3. truly avant-garde, in the late work of Glissant and Le Clézio. To put it concretely, both Glissant and Le Clézio developed their positions over the period from 1950 to 1970 through intensive engagement with prominent representatives of the avant-garde such as the Tel Quel group and Aimé Césaire. Both of them participated to a certain degree, but they were not able to implement the consistent radicalism of the following generations: with a manifesto and all of the characteristics that can be classified as avant-garde, the representatives of Créolité-the "sons"-put their faith in a paradigm shift. It is not until forty years later that a new (avant-gardist) paradigm is successfully formulated, which, though it does not explicitly call itself avant-garde, for that very reason in fact contains in itself a latent avant-garde dimension. 